F. Reprod. Fert. (1967) 13, 457-468

\title{
OBSERVATIONS ON PREGNANCY IN INTACT RABBITS AND IN OVARIECTOMIZED RABBITS TREATED WITH 17 $\alpha$-HYDROXYPROGESTERONE CAPROATE
}

\author{
STELLA PIGKWORTH* AND G. E. LAMMING \\ University of Nottingham School of Agriculture, Sutton Bonington, \\ Loughborough, Leicestershire
}

(Received 1st Fuly 1966, revised 22nd September 1966)

\begin{abstract}
Summary. Rabbits ovariectomized 24 hr post coitum (p.c.) were injected i.m. with $2 \mathrm{mg}$ or $4 \mathrm{mg} 17 \alpha$-hydroxyprogesterone caproate daily. Prenatal development was compared with that of control litters at 9 and 29 days, 5 days and 7 days p.c. The $2 \mathrm{mg}$ treatment supported $26.4 \%$ pre-natal survival to 29 days p.c., most mortality occurring between 7 and 9 days. The $4 \mathrm{mg}$ dose rate permitted $71.0 \%$ survival to 29 days p.c. which was not significantly different from controls $(81.5 \%)$. Blastocyst size at 5 days p.c. was not significantly affected by treatment but both ovariectomized groups showed slight retardation at 7 days when stage of attachment was assessed by observation and by analysis of blastocyst fluid for lactic acid. Attachment was least advanced in the group receiving the lower dose rate.

In 29-day foetuses the degree of ossification of the femur was positively related to foetus weight. In control litters deposition of calcium and total ash components and relative decrease in water content were also further advanced in the larger foetuses, suggesting a general association of size and maturity.
\end{abstract}

\section{INTRODUCTION}

The rabbit is normally dependent upon the presence of corpora lutea for the maintenance of pregnancy. Except in the very late stages, when extra-ovarian sources of hormones may be adequate (Csapo \& Lloyd-Jacob, 1962; Schofield, 1963), ovariectomy brings about a resorption or abortion of the litter. The literature contains many reports of maintaining pregnancy in the ovariectomized rabbit by treatment with substitution compounds, ranging from the early work with corpus luteum extracts (Allen \& Corner, 1929) to the more recent testing of synthetic compounds with progestational activity.

In many of the references available few criteria have been used to indicate

* Present address: Worcester Foundation for Experimental Biology, Shrewsbury, Massachusetts, U.S.A. 
successful treatment in addition to the obvious parameter of pre-natal survival rate, although many features of development in the rabbit are well documented. Examination in early pregnancy has included measurement of blastocyst size and use of the flat-mount technique (Moog \& Lutwak-Mann, 1958). The diameter of implantation swellings a few days after attachment also provides a measure of development and, to some extent, viability (Adams, 1959; Hafez, 1961). The normal pattern of foetal and placental growth in the rabbit was described by Hammond (1935) and detailed embryological development by Minot \& Taylor (1905). Characteristic changes in the chemical composition of blastocyst fluid accompany development (Lutwak-Mann, Boursnell \& Bennett, 1960; Lutwak-Mann, 1962) and Lutwak-Mann, Hay \& Adams (1962) observed that changes in lactic acid concentration apparently were associated with attachment and not merely with blastocyst growth. Although physiological maturity at the end of pregnancy has received little attention, certain features of chemical composition have been described in rabbit foetuses and newborn young (Widdowson, 1950; Lafon, 1960) and the ossification process was examined by Appleton (1929).

In 1960 when this work was started, the simplest and most promising substitution treatment for the maintenance of pregnancy in ovariectomized rabbits appeared to be that of Wu \& Allen (1959) using 17 $\alpha$-hydroxyprogesterone caproate (HPC). This compound had been tested in a small number of animals over a 28-day period of pregnancy. The data presented below were obtained from ovariectomized pregnant rabbits treated with this compound and from intact control animals. Examination was made at different stages of pregnancy to study the effects of suboptimum dosage on embryonic and foetal development. A preliminary communication of this work has already appeared (Pickworth, 1963).

\section{MATERIALS AND METHODS}

Three experiments were completed, each involving three treatment groupsone group of intact control animals and two groups of ovariectomized animals receiving respectively $2 \mathrm{mg}$ and $4 \mathrm{mg} 17 \alpha$-hydroxyprogesterone caproate. In Experiment $I$ the pregnant animals were examined by laparotomy 9 days post coitum (p.c.) and at autopsy 29 days p.c., the 9-day examination providing an interim, post-implantation, estimate of survival rate. In Experiment II the size of blastocysts was compared between treatments at 5 days p.c. and in Experiment III the stage of implantation was assessed at 7 days p.c.

Uniparous does were used from a closed colony of Dutch-belted rabbits. A rest period of 2 weeks was allowed after their first litter had been removed, then they were mated to one or two fertile bucks. Body weight, recorded at mating, ranged from 1.8 to $3.3 \mathrm{~kg}(90 \%$ between 1.9 and $2.6 \mathrm{~kg})$. A pelleted compound food (Coney Brand, B.O.C.M.) was provided without limit during the experiments.

Only small numbers of animals were available at any one time. Litter sisters were placed in separate treatment groups and, in Experiment III, the allocation of animals was partially directed to prevent very uneven distribution by body 
weight. Seven animals were allotted to each treatment in Experiments I and II, ten animals to each in Experiment III.

\section{Treatments}

All animals were anaesthetized 23 to $25 \mathrm{hr}$ p.c. and the number of ovulation points counted by examination of the ovaries through a midline or flank incision.

Treatment 1 (control): Examination only.

Treatment 2 (2 mg group): Bilateral ovariectomy, $2 \mathrm{mg}$ HPG daily.

Treatment 3 (4 mg group): As treatment 2 but $4 \mathrm{mg}$ HPG daily.

Counts of corpora lutea were made in all control animals at autopsy. Procedure in the individual experiments was as follows:

\section{Experiment I: Maintenance of pregnancy to 29 days p.c.}

All animals were laparotomized $215 \frac{1}{2}$ to $216 \frac{1}{2} \mathrm{hr}$ (9 days) p.c. Implantation sites were counted and the swellings measured across the axis of the uterine horn with vernier calipers (nearest $\frac{1}{4} \mathrm{~mm}$ ). The animals were then killed exactly 29 days p.c. The following weights were recorded: foetus, foetal placenta and membranes, maternal placenta, foetal fluids (by difference), uterine horn. Foetuses were sexed and the right femur removed for histological examination. Foetuses were dried in air at $55^{\circ} \mathrm{C}$ and subsequently analysed individually for content of fat (as ether extract), total nitrogen, total ash and calcium.

Experiment II: Blastocyst size at 5 days p.c.

Animals were killed $120 \mathrm{hr}$ p.c. The uterine horns and Fallopian tubes were flushed with Locke's solution or a 1:1 Locke's solution-serum mixture. Blastocysts were transferred to a small volume of fluid and measured with an ocular micrometer. The average of the largest and smallest diameters to the outside of the zona pellucida was calculated to the nearest $10 \mu$.

Experiment III: Stage of implantation at 7 days p.c.

Animals were killed $168 \mathrm{hr}$ p.c. Spacing of large blastocysts was measured approximately by laying the excised uterine horns on graph paper and marking the blastocyst positions (swellings or semi-translucent areas). Blastocysts were classed as 'free' (readily moved through the uterus by external pressure from one side), 'attached' or 'indefinite stage'. Free blastocysts were dissected out, transferred to a piece of polythene film and weighed. Fluid from the blastocyst cavity of those remaining was aspirated through the uterine wall, using a glass tuberculin syringe and short needle. All blastocyst material from a single animal was collected in a graduated centrifuge tube. Intact blastocysts (of unknown volume) were ruptured and measured volumes of distilled water were then added until the total fluid volume filled the tube to a standard level. The volume of the blastocyst material was obtained by difference, total minus water. The fluid was analysed for lactic acid.

The lumen of the dissected uterus was rinsed with saline to recover any small or degenerating eggs present. These were not included in the material for analysis. 
Surgical procedure and hormones

Surgery was carried out under Nembutal anaesthesia (Abbott Laboratories), supplemented with ether where necessary. No antibiotics were used but sterile precautions were observed.

Daily intramuscular injections of hormones were started at ovariectomy. The preparation used was $17 \alpha$-hydroxyprogesterone caproate (Primolut-Depot, Schering A.G.) diluted with ethyl lactate and castor oil to provide the required dose in $0.2 \mathrm{ml}$ volume.

\section{Chemical analysis}

Foetuses. Analysis was carried out on foetal material previously dried and stored in some instances for several months. The dried carcass was ground and extracted with petroleum ether (boiling range 40 to $60^{\circ} \mathrm{C}$ ). Ether extracts were estimated by direct weight. The fat-free residue was reground and further analysed for total nitrogen, total ash and calcium.

Lactic acid in blastocyst fluid. The fluid was shaken with four times its volume of $10 \%$ trichloracetic acid then diluted to 20 vol. with water, shaken and centrifuged $(10 \mathrm{~min}$ at $1500 \mathrm{rev} / \mathrm{min})$. Samples of $1 \mathrm{ml}$ of the supernatant were analysed by the method of Barker \& Summerson (1941), using standard preparations of lactic acid for comparison. Values were corrected to the nearest $5 \mathrm{mg} \%$.

\section{Histological procedure}

The femurs were fixed in $90 \%$ alcohol, dehydrated, cleared and embedded in wax for serial sectioning at a thickness of $8 \mu$. Appropriate sections were stained with Alizarin Red S, and usually counterstained with Polychrome Methylene Blue (Unna). Development of ossification in the distal epiphysis was assessed on a scale of 1 to $3: 1$ - small area of hypertrophied cartilage cells; 2-advanced hypertrophy with developing calcification; 3-breakdown of calcified cartilage, infiltration of blood vessels.

\section{RESULTS}

\section{Ovulation number and fertilization}

In the combined data of Experiments I, II and III the mean number of ovulation points per animal was $8 \cdot 1 \pm 0 \cdot 6$ (range 5 to 12). Unfertilized eggs were found only in four subsequently discarded animals where complete failure of fertilization occurred.

\section{Experiment I: Maintenance of pregnancy to 29 days p.c.}

Survival rates were expressed in terms of ovulation points represented by implantation sites at 9 days and live foetuses at 29 days p.c. (Table 1). One animal (treatment 2) was not pregnant at 9 days p.c. and was discarded from the data on grounds of possible fertilization failure. A $\chi^{2}$ test indicated a lower overall survival of ovulations $(P<0.001)$ in treatment 2 animals $(2 \mathrm{mg}$ HPC) than in the treatment 1 , control animals, or treatment $3(4 \mathrm{mg})$. There was no significant difference between treatments 1 and 3 . The survival rate between 
9 and 29 days was high with no significant differences between groups. Consequently, survival throughout pregnancy followed the 9-day pattern.

The mean diameter of implantation sites within animals at 9 days p.c. was smaller $(P<0.05)$ in the $4 \mathrm{mg}$ group than in the controls, but the difference was no longer significant when non-viable sites were excluded (those not occupied by a live foetus at 29 days p.c.) (Table 2). The mean implantation size in the $2 \mathrm{mg}$ group was smaller than in either of the other treatments but the survival rate to 9 days was too low to provide adequate comparison. At 9 days this group carried one litter of seven implantations, one of three, two of two and two of one implantation.

At 29 days p.c. one dead foetus was found in a $2 \mathrm{mg}$ group animal; all other 9 to 29 day failures (nine) were represented by an atrophic placenta. Litter size in control animals ranged from four to eleven foetuses. Six of the $4 \mathrm{mg}$ group animals carried from four to ten foetuses, the seventh animal had only a single living foetus. Where inclusion of this foetus in the data altered statistical significance of treatment differences, the results are quoted separately for six

TABLE 1

PRENATAL SURVIVAL RATES TO 9 AND 29 DAYS P.C. (OVULATIONS REPRESENTED BY IMPLANTATIONS OR LIVE YOUNG)

\begin{tabular}{l|c|c|c|c|c|c|c}
\hline & \multirow{2}{*}{$\begin{array}{c}\text { No. } \\
\text { Treatment }\end{array}$} & $\begin{array}{c}\text { No. } \\
\text { ovulations }\end{array}$ & $\begin{array}{c}\text { No. } \\
\text { implant- } \\
\text { ations }\end{array}$ & $\begin{array}{c}\text { No. } \\
\text { live young }\end{array}$ & $\begin{array}{c}1 \text { to } 9 \\
\text { days }\end{array}$ & $\begin{array}{c}9 \text { to } 29 \\
\text { days }\end{array}$ & $\begin{array}{c}1 \text { to } 29 \\
\text { days }\end{array}$ \\
\hline 1 (control) & 7 & 54 & 48 & 44 & 88.9 & $91 \cdot 7$ & 81.5 \\
$2(2 \mathrm{mg} \mathrm{HPC})$ & 6 & 53 & 16 & $14 *$ & 30.2 & 87.5 & 26.4 \\
$3(4 \mathrm{mg} \mathrm{HPC})$ & 7 & 62 & 48 & 44 & $77 \cdot 4$ & 91.7 & 71.0 \\
\hline
\end{tabular}

* Includes two 28-day foetuses.

and seven litters. In the $2 \mathrm{mg}$ group one animal was killed 28 days p.c.; the litters of the other five animals totalled only twelve live foetuses. Statistical comparison of foetal measurements was therefore confined to control and $4 \mathrm{mg}$ group data.

The male-female ratio of live foetuses was $24: 20$ in controls, $7: 7$ in $2 \mathrm{mg}$ animals and 26:18 in the $4 \mathrm{mg}$ group.

Weight measurements at 29 days p.c. Results are shown in Table 2. Mean foetus weight per litter in the control group was greater $(P<0.01)$ than in $4 \mathrm{mg}$ group animals. There was no constant relationship between foetus weight and number of foetuses per uterine horn or relative position in the horn; the data available were inadequate for assessing the influence of maternal body weight on foetus weights. Treatment differences in foetal fluid or foetal placenta weights were not significant. The difference in weight of maternal placenta was significant $(P<0.05)$ when the animal carrying a single foetus was omitted from the $4 \mathrm{mg}$ data. Individual foetus weight was correlated with weight of foetal placenta and membranes: control $r=+0.528(P<0.001) ; 4 \mathrm{mg}$ group $r=+0.887(P<0.001)$. There was a weak positive correlation between weights 
of foetus and maternal placenta, which reached the $P<0.05$ level in the control group only.

Ossification. All live foetuses showed some development of the ossification centre in the distal epiphysis of the femur (Table 3). Three foetuses were omitted from the data owing to faults in section preparation. The association of the most advanced ossification stage with high foetus weights was largely a between-litter effect but it was also apparent within some litters.

TABLE 2

DIAMETER OF IMPLANTATION SITES AT 9 DAYS p.C. AND WEIGHTS OF CONGEPTION PRODUCTS AT 29 DAYS p.C. (MEAN士s.E.; BASED ON LITTER MEANS)

\begin{tabular}{|c|c|c|c|c|c|c|}
\hline \multirow{2}{*}{ Treatment } & \multicolumn{2}{|c|}{ Implantation site (mm) } & \multicolumn{4}{|c|}{ Conceptus weight $(g)$} \\
\hline & All & Viable & Foetus & Foetal fluid & $\begin{array}{l}\text { Foetal placenta } \\
\text { and membranes }\end{array}$ & $\begin{array}{l}\text { Maternal } \\
\text { placenta }\end{array}$ \\
\hline $\begin{array}{c}1 \\
\text { (control) }\end{array}$ & $\begin{array}{r}13.5 \\
\pm 0.4\end{array}$ & $\begin{array}{r}13 \cdot 6 \\
\pm 0.4\end{array}$ & $\begin{array}{r}41 \cdot 66 \\
\pm 1 \cdot 05\end{array}$ & $\begin{array}{r}1 \cdot 15 \\
\pm 0.21\end{array}$ & $\begin{array}{r}5 \cdot 17 \\
\pm 0.22\end{array}$ & $\begin{array}{r}0.94 \\
\pm 0.08\end{array}$ \\
\hline$(2 \mathrm{mg}$ HPC $)$ & $\begin{array}{r}10.5 \\
\pm 0.7\end{array}$ & $\begin{array}{r}10 \cdot 5 \\
\pm 0.9\end{array}$ & $\begin{array}{c}37.62 \\
\pm 1.61^{*}\end{array}$ & $\begin{aligned} & 1.77 \\
\pm & 0.25 *\end{aligned}$ & $\begin{array}{c}6.95 \\
+0.82^{*}\end{array}$ & $\begin{array}{l}1 \cdot 07 \\
\pm 0 \cdot 19 *\end{array}$ \\
\hline $\begin{array}{c}3 \\
\text { (4 mg HPC) }\end{array}$ & $\begin{array}{r}12 \cdot 3 \\
\pm 0 \cdot 3\end{array}$ & $\begin{array}{r}12 \cdot 7 \\
\pm 0 \cdot 2\end{array}$ & $\begin{array}{r}33.94 \\
\pm 1.87\end{array}$ & $\begin{array}{r}1.67 \\
\pm 0.25\end{array}$ & $\begin{array}{r}5.55 \\
\pm 0.36\end{array}$ & $\begin{array}{r}1.12 \\
\pm 0 \cdot 11\end{array}$ \\
\hline
\end{tabular}

* Four litters.

TABLE 3

OSSIFIGATION IN FOETAL FEMURS AT 29 DAYs p.c. - NUMBER OF FOETUSES AND FOETUS WEIGHTS (MEAN \pm S.E., LITTER DIVISIONS DISREGARDED)

\begin{tabular}{l|c|c|c|c|c|c}
\hline \multirow{2}{*}{ Treatment } & \multicolumn{3}{|c|}{ No. of foetuses } & \multicolumn{3}{c}{ Foetus weight $(\mathrm{g})$} \\
\cline { 2 - 7 } & Grade 1 & Grade 2 & Grade 3 & Grade 1 & Grade 2 & Grade 3 \\
\hline 1 (control) & 4 & 15 & 24 & $*$ & $38 \cdot 34 \pm 1 \cdot 05$ & $43 \cdot 80 \pm 0.57$ \\
$2(2 \mathrm{mg} \mathrm{HPC})$ & 1 & 9 & 2 & $*$ & $37 \cdot 76 \pm 1 \cdot 44$ & $*$ \\
$3(4 \mathrm{mg} \mathrm{HPC})$ & 21 & 8 & 13 & $30 \cdot 78 \pm 1 \cdot 49$ & $33 \cdot 38 \pm 1 \cdot 89$ & $39 \cdot 14 \pm 1 \cdot 49$ \\
\hline
\end{tabular}

Grades defined in 'Methods' section.

Foetus weight differences between grades: Treatment 1-grade 3: grade 2, $P<0.001$; Treatment 3grade 3: grade 2, $P<0.05$; grade 3 : grade $1, P<0.001$; grade 2: grade 1, n.s.d.

* Four or less foetuses.

Chemical analysis. The ether extract fraction of the material was very variable and other components were compared on a fat-free basis (Table 4). The $4 \mathrm{mg}$ treatment foetuses showed a lower percentage of total ash than the controls $(P<0.001)$, a lower percentage calcium $(P<0.001)$ and a wider ash-calcium ratio $(P<0.001$; excluding the one-foetus litter $P<0.01)$. The moisture content was slightly higher than in control litters $(P<0.05)$. There was no treatment difference in total nitrogen or ether extract. Three litters (six foetuses) from the $2 \mathrm{mg}$ group were available for analysis and composition resembled that of the $4 \mathrm{mg}$ group foetuses.

Correlations between total foetus weight and the water, ash and calcium 
percentage of fat-free weight in control foetuses were, water $r=-0.446$ $(P<0.01)$, ash $+0.456(P<0.01)$ and calcium $+0.550(P<0.001)$. The same calculations for $4 \mathrm{mg}$ group foetuses gave $r=-0.451 \quad(P<0.01),+0.425$ $(P<0.01)$ and +0.268 (not significant) respectively. Treatment differences in composition could not be explained entirely by differences in foetus weight; within the main weight range common to both groups the calcium and ash values were noticeably lower in the experimental group than in the controls.

\section{TABLE 4}

CHEMICAL COMPONENTS OF FOETUSES AT 29 DAYS p.c. (g/100 g FAT-FREE WEIGHT, MEAN \pm S.E., BASED ON LITTER MEANS)

\begin{tabular}{c|c|c|c|c|c|c|c}
\hline Treatment & $\begin{array}{c}\text { No. } \\
\text { litters }\end{array}$ & Water & $\begin{array}{c}\text { Total } \\
\text { nitrogen }\end{array}$ & $\begin{array}{c}\text { Total } \\
\text { ash }\end{array}$ & Calcium & $\begin{array}{c}\text { Total ash/ } \\
\text { calcium }\end{array}$ & $\begin{array}{c}\text { Ether* } \\
\text { extract }\end{array}$ \\
\cline { 2 - 6 } & 7 & 84.98 & 1.81 & 2.05 & 0.42 & 4.84 & 4.74 \\
(control) & 7 & \pm 0.13 & \pm 0.02 & \pm 0.03 & \pm 0.01 & \pm 0.04 & \pm 0.14 \\
2 & 3 & 85.41 & 1.79 & 1.89 & 0.36 & 5.32 & 3.38 \\
$(2 \mathrm{mg} \mathrm{HPC})$ & 7 & \pm 0.33 & \pm 0.03 & \pm 0.05 & \pm 0.02 & \pm 0.17 & \pm 0.27 \\
3 & 7 & 85.43 & 1.80 & 1.88 & 0.35 & 5.33 & 4.63 \\
$(4 \mathrm{mg} \mathrm{HPC})$ & & \pm 0.15 & \pm 0.02 & \pm 0.02 & \pm 0.01 & \pm 0.09 & \pm 0.48 \\
\hline
\end{tabular}

* Ether extract expressed as $\mathrm{g} / 100 \mathrm{~g}$ total foetus weight.

TABLE 5

REGOVERY AND SIZE OF 5-DAY BLASTOCYSTS

\begin{tabular}{|c|c|c|c|c|c|c|c|}
\hline \multirow{2}{*}{ Treatment } & \multirow{2}{*}{$\begin{array}{l}\text { No. } \\
\text { does }\end{array}$} & \multicolumn{2}{|c|}{ Ovulations } & \multicolumn{3}{|c|}{ Blastocysts recovered } & \multirow{2}{*}{$\begin{array}{c}\text { Diameter of } \\
\text { normal blasto } \\
\text { cysts }(m m) * \\
(\text { mean } \pm S . E .)\end{array}$} \\
\hline & & Total & Mean $\pm S . E$ & Normal & $\begin{array}{c}\text { Dead or } \\
\text { abnormal }\end{array}$ & Missing & \\
\hline $\begin{array}{c}1 \\
\text { (control) }\end{array}$ & 7 & 50 & $\begin{array}{r}7.1 \\
\pm 0.1\end{array}$ & $\begin{array}{l}41 \\
(82 \%)\end{array}$ & 2 & 7 & $\begin{array}{r}1.04 \\
\pm 0.09\end{array}$ \\
\hline$\left(\begin{array}{c}2 \\
(2 \mathrm{mg} \text { HPC }\end{array}\right.$ & 7 & 53 & $\begin{array}{r}7.6 \\
\pm 0.6\end{array}$ & $\begin{array}{l}41 \\
(77 \%)\end{array}$ & 2 & 10 & $\begin{array}{r}0.93 \\
\pm 0.05\end{array}$ \\
\hline $\begin{array}{c}3 \\
(4 \mathrm{mg} \mathrm{HPC})\end{array}$ & 7 & 62 & $\begin{array}{r}8.9 \\
\pm 0.7\end{array}$ & $\begin{array}{l}51 \\
(82 \%)\end{array}$ & 4 & 7 & $\begin{array}{r}0.91 \\
\pm 0.05\end{array}$ \\
\hline
\end{tabular}

* Based on litter means.

Experiment II: Blastocyst size at 5 days p.c.

Results are shown in Table 5. The mean number of ovulations was greater in the $4 \mathrm{mg}$ group than in the controls $(P<0.05)$; other ovulation differences were not significant. A $\chi^{2}$ test showed no treatment differences in the proportion of ovulations represented by 'normal' blastocysts (those which had undergone some expansion and showed no obvious abnormalities).

Diameter of blastocysts varied greatly, particularly in the control group (Text-fig. 1) and treatment differences were not significant in the unweighted data. No relationship was found between mean blastocyst diameter/uterine horn and number/horn or between mean diameter/litter and either number/ litter or maternal weight. 
Experiment III: Stage of implantation at 7 days p.c.

There was no significant treatment difference in survival of blastocysts up to Day 7 (Table 6). No abnormal spacing of blastocysts was observed. Three degenerating eggs were found in a $4 \mathrm{mg}$ group doe and one in each of two control animals.
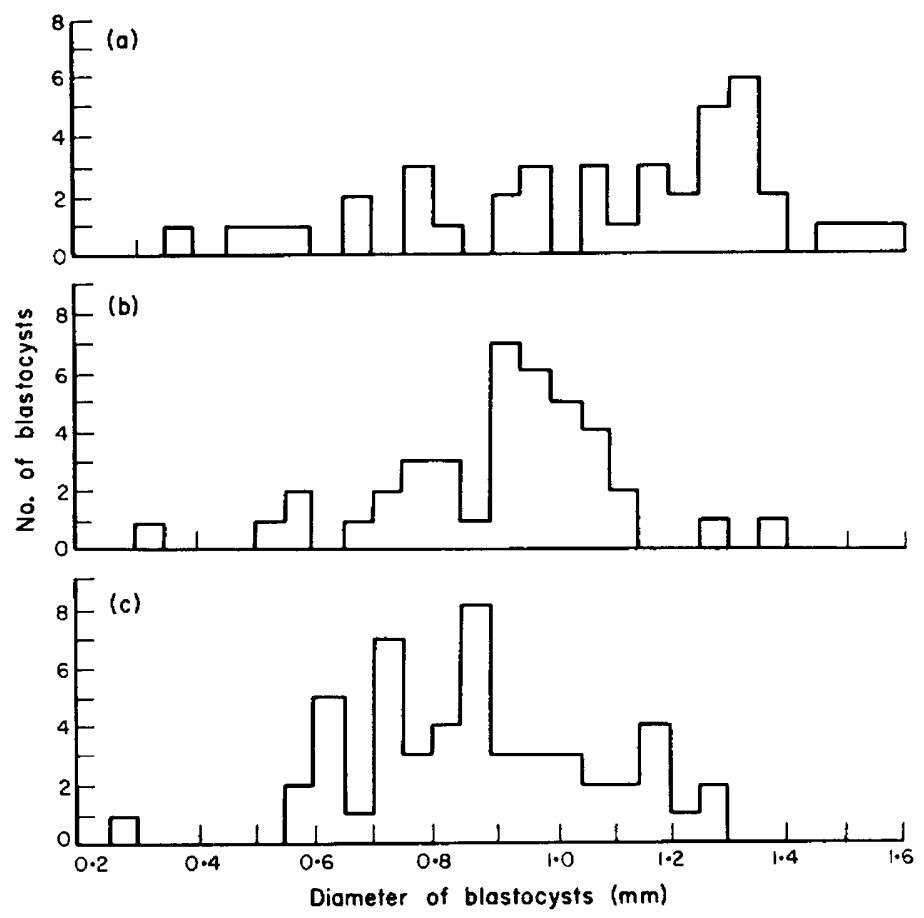

TeXr-Fig. 1. Diameter of blastocysts at 5 days p.c. (a) Control, (b) $2 \mathrm{mg} \mathrm{uPC,} \mathrm{(c)} 4 \mathrm{mg} \mathrm{HPC}$.

TABLE 6

RECOVERY OF BLASTOGYSTS AND STAGE OF IMPLANTATION AT 7 DAYS p.c.

\begin{tabular}{|c|c|c|c|c|c|c|c|c|}
\hline \multirow{2}{*}{ Treatment } & \multirow{2}{*}{$\begin{array}{c}\text { No. } \\
\text { ovulations }\end{array}$} & \multirow{2}{*}{$\begin{array}{c}\text { No. normal } \\
\text { blastocysts } \\
\text { recovered }\end{array}$} & \multicolumn{3}{|c|}{ No. of litters } & \multicolumn{3}{|c|}{ No. of blastocysts } \\
\hline & & & $\begin{array}{l}\text { All } \\
\text { free }\end{array}$ & $\begin{array}{c}\text { Mixed or } \\
\text { indefinite } \\
\text { stage }\end{array}$ & $\begin{array}{c}\text { All } \\
\text { altached }\end{array}$ & Free & $\begin{array}{l}\text { Indefinite } \\
\text { stage }\end{array}$ & Attached \\
\hline 1 (control) & 80 & 70 & 1 & 3 & 6 & 10 & 7 & 53 \\
\hline $2(2 \mathrm{mg} \mathrm{HPC})$ & 81 & 71 & 7 & 3 & - & 64 & 3 & 4 \\
\hline 3 (4 mg HPC) & 83 & 70 & 3 & 6 & 1 & 36 & 7 & 27 \\
\hline
\end{tabular}

The proportion of blastocysts in the 'attached' class was greater in the control animals than in either hormone treated group $(P<0.001)$ and was greater in the $4 \mathrm{mg}$ than $2 \mathrm{mg}$ group (Table 6). Support for this observation was provided by the association in all groups between lactic concentration of blastocyst fluid 
and assessed stage of attachment. In litters containing only free blastocysts, lactic acid concentration ranged between 15 and $40 \mathrm{mg} / 100 \mathrm{ml}$. The corresponding value for litters of 'attached' blastocysts was 50 to $105 \mathrm{mg} / 100 \mathrm{ml}$ (Text-fig. 2). Where the stage of implantation varied within the litter, the analysed fluid contained all the fluid from free blastocysts but only a portion from the others, from which it was withdrawn by syringe. When allowance was made for the relative proportions of these sources the results showed the same trend towards increasing lactic acid concentration as attachment occurred. A bias towards low lactic acid estimates was incurred where free blastocysts

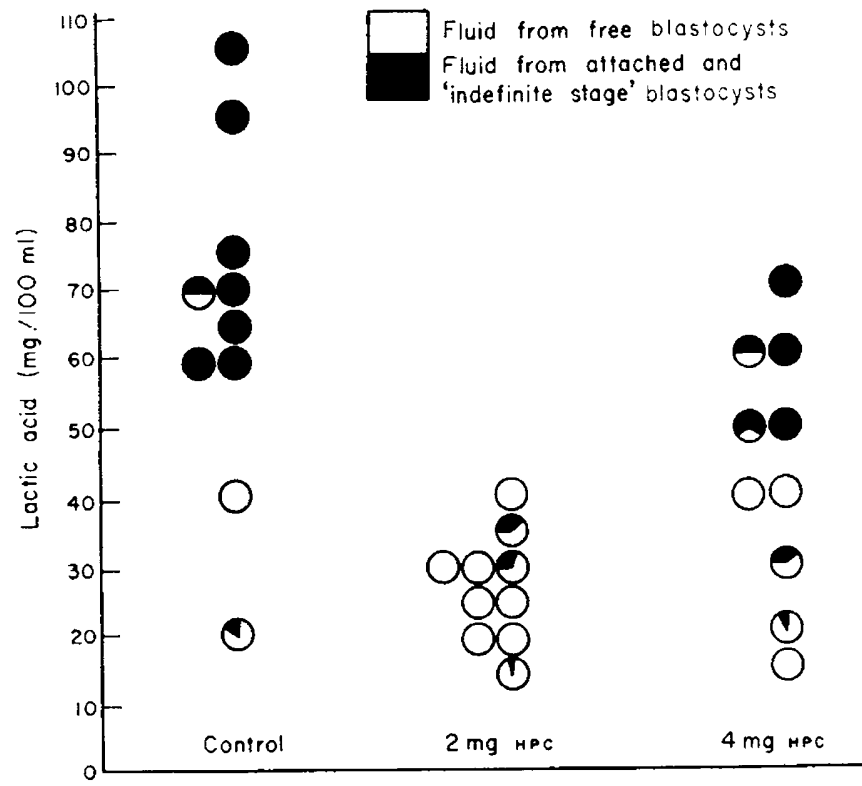

TEXT-FIG. 2. Relationship between assessed stage of attachment and lactic acid concentration in blastocyst fluid. Each circle represents bulked fluid from one rabbit.

were present, owing to the inclusion of cellular material in the initial volume, but this was insufficient to alter the general conclusions.

Weights of the free blastocysts ranged from 4 to $92 \mathrm{mg}$. The mean weight of blastocysts from the 'all-free' $2 \mathrm{mg}$ group litters was $36 \pm 5 \mathrm{mg}$.

\section{DISCUSSION}

The seven control animals examined at 29 days p.c. showed a loss of $18.5 \%$ of recorded ovulations, low by comparison with laboratory rabbits examined by Adams (1959) although not conclusive in such a small sample. Failure of established implantations accounted for $7.5 \%$ of ovulations. Placental remnants but absence of foetuses at these sites suggested foetal death earlier than 17 days p.c. (Adams, 1959).

Differences in survival rate between controls and the $2 \mathrm{mg}$ ovariectomized group arose between 7 and 9 days p.c., covering the period of implantation. Post-implantation survival rates were high in all groups, however, and fourteen 
of the sixteen implantations under the $2 \mathrm{mg}$ treatment were alive in late pregnancy (Table 1). A constant $2 \mathrm{mg}$ dose rate was tested by Wu \& Allen (1959) in only three animals but in each the pre-natal survival rate was high. An initial dose rate below $2 \mathrm{mg}$, raised to $2 \mathrm{mg}$ on the 6th day p.c., was found to be inadequate but unlike the suboptimal dose rate in the present experiment it resulted mainly in resorption after the time of implantation. Potential sources of difference in the present results include the animals and the hormone diluent. Wu and Allen diluted HPC with sesame oil, while a mixture of ethyl lactate and castor oil was used here. Kessler \& Borman (1957) compared the latter mixture with a benzyl benzoate-sesame oil combination as a vehicle for HPG in the Glauberg test and found it the slower of the two in producing a response. This suggests that the effects of the $2 \mathrm{mg}$ dose rate in the present work may have been those of a temporary inadequacy in very early pregnancy rather than of a completely inadequate dosage level. The effects of any such delayed response were less noticeable with the higher dose rate.

Blastocyst size was very variable in all groups at 5 days p.c. but two days later treatment differences were clear, with attachment in both hormonetreated groups lagging behind the control stage. Analysis of blastocyst fluid showed an increase in lactate concentration with observed attachment (LutwakMann, 1962) and provided quantitative support for the visual assessment. Presumably the delayed attachment in the $4 \mathrm{mg}$ group would have had little effect on survival rate since litter size at 29 days p.c. was approximately normal in the first experiment. By analogy, the majority of 7-day blastocysts in the $2 \mathrm{mg}$ group would not have been successful; whether or not any attempt at implantation occurred in the first experiment is not known, since the animals were allowed to continue through pregnancy and could not be examined in detail at 9 days.

In the control and $4 \mathrm{mg}$ groups ossification of the femur was more advanced in the heavier foetuses, as described by Appleton (1929). A greater proportion of control foetuses showed the most advanced ossification stage than did foetuses from hormone-treated groups, but the control foetuses were also the heavier (Table 3). The material was not sufficient to show any effect of treatment independent of foetus weight differences.

In terms of water, nitrogen and calcium, the chemical composition of control foetuses approximated that of newborn young examined by Widdowson (1950). Correlations between control foetus weight and ash, calcium and water percentage were of low order but in accord with bone development. The association between weight and aspects of maturation appeared to be a genuine trend through the control material and did not rest upon a retarded state of abnormally small foetuses.

The sex of the foetus had no measurable effect on any of the results obtained.

In the absence of evidence from intermediate stages of pregnancy it is possible only to speculate that treatment differences between 29-day foetuses were the continuation of a disparity established by 7 days p.c. The most severely affected blastocysts presumably did not survive the implantation period. Some successful implantations occurred in the $2 \mathrm{mg}$ group so the uterus was evidently receptive. The 7 -day results did not show any particularly favoured site for 
this attachment. There was good recovery of blastocysts up to this time and the observed retardation was not very great. Possibly the survivors differed from the group majority in an ability to withstand a formerly and perhaps currently unfavourable uterine environment, which rendered the others unable to implant successfully. Alternatively, the majority of slightly retarded blastocysts may have been potentially viable but unable to become attached within the receptive period produced by the treatment. The latter possibility could be explored by transfer to a chronologically 'younger' uterus.

Treatment with $17 \alpha$-hydroxyprogesterone caproate produced no observable ill effects in either the mature rabbits or surviving foetuses. The high placental weights in the hormone-treated groups were at variance with the reverse trend in foetus weights. The maternal placenta normally reaches its maximum size by about the 16th day and regresses in late pregnancy (Hammond, 1935). The treatment may have stimulated placental growth or may have interfered with regression in a way perhaps related to the constant dose rate of HPC throughout pregnancy. Using the Hooker-Forbes assay, Zarrow \& Neher (1955) found progressively increasing amounts of circulating progestational materials in intact pregnant rabbits. It is evident, though, that changes in proportion of different compounds must occur, since circulating levels of progesterone decrease in the latter half of pregnancy (Mikhail, Noall \& Allen, 1961).

\section{ACKNOWLEDGMENTS}

This study was carried out during the tenure of a Ministry of Agriculture Postgraduate Studentship (S.P.) and subsequently assisted by the University of Nottingham Belper Scholarship Fund. The authors are indebted to Messrs Schering A.G., Berlin, for the supply of Primolut-Depot, and to the following people for valuable technical assistance: Miss Ayliffe Hervey, Miss Elizabeth Allen, Mr D. MacLean and Mr D. G. Jones.

\section{REFERENCES}

Adams, C. E. (1959) Studies on prenatal mortality in the rabbit, Oryctolagus cuniculus: the amount and distribution of loss before and after implantation. 7. Endocr. 19, 325.

Allen, W. M. \& Corner, G. W. (1929) Physiology of the corpus luteum. III. Normal growth and implantation of embryos after very early ablation of the ovaries, under the influence of extracts of the corpus luteum. Am. F. Physiol. 88, 340.

Appleton, A. B. (1929) The relation between the rate of growth and the rate of ossification in the foetus of the rabbit. C.r. Ass. Anat. 24, 3.

Barker, S. B. \& Summerson, W. H. (1941) The colorimetric determination of lactic acid in biological material. 7. biol. Chem. 138, 535.

Csapo, A. \& LloYd-JACOB, M. A. (1962) Placenta, uterine volume and the control of the pregnant uterus in rabbits. Am. F. Obstet. Gynec. 83, 1073.

HAFEZ, E. S. E. (1961) Embryonic survival in relation to number and size of implantation swellings in the rabbit, Oryctolagus cuniculus. Proc. Soc. exp. Biol. Med. 107, 680.

Hammond, J. (1935) The change in the reproductive organs of the rabbit during pregnancy. Trudy Din. Razv. 10, 93.

Kessler, W. B. \& Borman, A. (1957) Comparison of duration of action of progesterone and 17- $\alpha$ hydroxyprogesterone-17n-caproate. Proc. Soc. exp. Biol. Med. 94, 820.

LAfon, M. (1960) Quelques aspects de la déhydration de l'organisme au cours de développement: observations biochimiques sur le lapin et le rat. Archs int. Physiol. Biochim. 68, 460. 
Lutwak-ManN, C. (1962) Glucose, lactic acid and bicarbonate in rabbit blastocyst fluid. Nature, Lond. $193,653$.

Lutwak-Mann, G., Boursnell, J. C. \& Bennett, J. P. (1960) Blastocyst-uterine relationships: uptake of radioactive ions by the early rabbit embryo and its environment. F. Reprod. Fert. 1, 169.

Lutwak-ManN, C., Hay, M. F. \& Adams, C. E. (1962) The effect of ovariectomy on rabbit blastocysts. 7. Endocr. 24, 185.

Mikhail, G., Noall, M. W. \& Allen, W. M. (1961) Progesterone levels in the rabbit ovarian vein blood throughout pregnancy. Endocrinology, 69, 504.

Minot, G. S. \& TAYLOR, E. (1905) Normal plates of the development of the rabbit (Lepus cuniculus L.). Normentafeln zur Entwicklungsgeschichte der Wirbelthiere, No. 5.

Moog, F. \& Lutwak-MaNN, G. (1958) Observations on rabbit blastocysts prepared as flat mounts. 7. Embryol. exp. Morph. 6, 57.

Pickworth, S. (1963) Maintenance of pregnancy in the ovariectomized rabbit. F. Reprod. Fert. 6, 328.

Schofield, B. M. (1963) The 'local' effect of the placenta on myometrial activity in the rabbit. $\mathcal{F}$. Physiol., Lond. 166, 191.

Widnowson, E. M. (1950) Chemical composition of newly born mammals. Nature, Lond. 166, 626.

Wu, D. H. \& AlLEN, W. M. (1959) Maintenance of pregnancy in castrated rabbits by 17-alphahydroxyprogesterone caproate and by progesterone. Fert. Steril. 10, 439.

Zarrow, M. X. \& Neher, G. M. (1955) Concentration of progestin in the serum of the rabbit during pregnancy, the puerperium and following castration. Endocrinology, 56, 1 . 